\title{
Reinforcing Cultural Hegemony: Pākehā Perceptions of Brand New Zealand
}

\author{
EVELINE DÜRR
}

National branding has become a prominent practice to favourably position a country in the economic sphere and to promote attractive images to both a local constituency and the global market. As a form of representation, however, branding is not only an economic project, it is also culturally engaged. Creating and disseminating messages about particular nations is tied into both the social construction of place and conceptions of nationhood. Branding evokes imagery of place, which shapes not only foreign perceptions but also identity formations of the nation's residents. At the same time, branding is informed by consumer practices and the social context in which it emerges and operates. Thus, branding entails a reciprocal effect and is mutually constructed by the agents of image-making and the expectations of image-consumers.' This points to the cultural significance of marketing representations, which need to be understood in the wider frame of sociocultural conditions, political ideologies and dominant discourses about particular places.

This article ${ }^{2}$ explores the entanglement and mutual constitution of New Zealand's branding strategies, national identity and local understandings of 'New Zealandness'. ${ }^{3}$ Emphasis is placed on Pākehă $\bar{a}^{4}$ perceptions of Tourism New Zealand's global campaign ' $100 \%$ Pure' and the ways individuals make sense of, and meaningfully translate, representations of New Zealand into their life-worlds. The study draws on life-story interviews and participant observation with third and fourth generation Pākehā New Zealanders. Hence, the data presented illuminates the subjectivities, experiences and understandings of a specific population segment. ${ }^{5}$ I argue that participants' interpretations of New Zealand's 'purity' reflect their perceptions of what makes New Zealand distinct and unique - just as the '100\% Pure New Zealand' campaign suggests distinctiveness and uniqueness to potential tourists. This distinctiveness includes a range of characteristics, such as cultural tolerance, social equity and exceptional inter-ethnic relations of which the Treaty of Waitangi is seen as proof. Such understandings of purity highlight that the branding of New Zealand as '100\% Pure' has 
evolved beyond the country's image as 'green and clean' and entails a much wider repertoire. Notions of purity, as evident in Pākehā narratives, also create a specific perception of nationhood and place. Even though the ' $100 \%$ Pure' branding strategy is primarily aimed at the globalised tourist market, it also has a significant impact on local perceptions of 'New Zealandness' and on the formation of a particular national imaginary. The myriad meanings of purity are conceived of as almost stereotypical 'national characteristics' that reinforce New Zealand's inimitability and provide a source of identity and national pride which is mediated and fostered by powerful representations.

This study also reveals that branding strategies and representations of ' $100 \%$ Pure New Zealand' cater mostly to Pākehā interests, ultimately strengthening hegemonic discourses and reproducing cultural dominance. I illustrate my argument by showing that Pākehā perceptions of ' $100 \%$ Pure New Zealand' are in line with New Zealand's international reputation, as promoted by Tourism New Zealand, as an ecologically friendly country where people live close to nature and in a relatively peaceful, egalitarian and tolerant society. But these perceptions are, to some extent, in conflict with both the colonial experience and contemporary social conditions. This is particularly evident in the more recent context of migration and New Zealand's growing multicultural society. The ongoing alteration of New Zealand's cultural composition challenges national identity constructions based on an ideal of a predominantly white, but tolerant and non-racist, society.

In order to contextualise my findings in the wider frame of New Zealand's representations and identity formations, I apply a historical perspective and first sketch out patterns of advertising in colonial New Zealand. I then detail more recent branding campaigns which both build on and enhance earlier images of the country. I situate Tourism New Zealand strategies in the context of globalisation and neoliberalism in which there is a need to develop a unique and distinct, but still adjustable, image of New Zealand which corresponds to the diversity of its market. Effective promotion to a variety of markets requires a range of appealing products and ideas which are portrayed as typical features of New Zealand and are saturated with 'New Zealandness'. This has seen the ' $100 \%$ Pure New Zealand' slogan evolve beyond imaginaries of pristine nature and scenic beauty. I also argue that the success of the brand ' $100 \%$ Pure New Zealand' is related to the vagueness of the term, which stimulates and allows for diverse associations and fantasies, but still localises them by depicting 'purity' as an inherently New Zealand characteristic. In conclusion, I shed light on the interplay of identity constructions and spatial representations which are embedded in the global tourist market. 


\section{Advertising New Zealand in a colonial and global frame}

New Zealand has a long and well-documented history of advertising and tourist promotion which dates back to even before 1901, when the Department of Tourist and Health Resorts was set up as one of the first national tourist departments in the world. Early advertising strategies were mainly directed at the market in the English mother country and embedded in a colonial context. Positive national images alluding to the achievements of empire were not only used to attract visitors to the remote islands but also potential residents and investors. ${ }^{6}$ Hence, not only was New Zealand's natural scenery advertised as attractive and distinct in the nineteenth century, but so too was the colonial society, with particular emphasis placed on the economic situation and frontier condition. Given the relatively high wages in colonial New Zealand, the disparities between workers and small businessmen were not as big as in Great Britain or other parts of Europe.? In New Zealand, lifestyle was similar for the majority of settlers, representing a levelling of the nineteenth-century British class system and creating a sense of equality. In addition, the country's pastures raised hopes for economic prosperity and a better future, one unlikely to be found in Great Britain. New Zealand's natural environment was idealised and portrayed as fertile and abundant, developing the myth of New Zealand as a 'better' or 'brighter' Britain of the South. ${ }^{8}$ This fostered the perception of a society without real poverty but with equal opportunities - a 'glorious country for a working man'. A male comradeship known as 'mateship', similarly implying a classless society, framed this promising and prosperous future discursively and ideologically. ${ }^{10}$

However, these conceptions disguised discrepancies and social exclusion in the Pākehā-dominated society, particularly in terms of gender and cultural difference. Pākehā men earned about twice as much as women, and, in comparison to other countries, few women were part of the paid workforce in New Zealand before World War Two." The egalitarian myth was further fuelled by the social reforms of the 1890s. ${ }^{12}$ Mãori, however, could hardly participate in economic progress and were subject to discrimination and deprivation. Regardless of the desperate situation of the indigenous people, the Treaty of Waitangi continued to be ignored. Nevertheless, progressive legislation - including legislation which, in 1893, made New Zealand the first self-governing nation in the world to grant all adult women, including Māori, the vote ${ }^{13}$ - contributed to the country's democratic and egalitarian reputation on an international stage. This reputation has been perpetuated ever since.

Like other British dominions, New Zealand struggled to create distinct cultural symbols of identification and international tourist appeal capable of competing with those of Europe, such as art or architecture. ${ }^{14}$ Early 
icons paralleled an American-style emphasis on the natural environment. In international tourist agencies established in other British colonies, the country was represented as a 'scenic wonderland. ${ }^{15}$ Advertisements included natural spas, in particular in the Rotorua area, which caught the attention of European visitors even after the complete destruction of the famous Pink and White Terraces in 1886. The loss of this spectacular tourist magnet made the government even more aware of the significant economic value of natural sites. ${ }^{16}$ However, New Zealand still struggled to create a 'unique' identity, and various symbols circulated to represent the country. ${ }^{17}$ In addition to nature, Māori culture was part of New Zealand's attraction and exotic appeal. ${ }^{18}$ This remained the case into the twentieth century, although control and power over the cultural representation of Māori would become a contested issue..$^{9}$

The emphasis on nature also continued through the twentieth century. By the 1980s, emerging new trade opportunities and globalisation processes had re-shaped the country's economy. As New Zealand expanded its transnational linkages, tourism increasingly gained momentum as a lucrative commercial activity. In the age of jet travel and mass tourism, New Zealand revised its advertising strategies. It appealed to tourists by inviting them to enjoy sporting and other outdoor activities in a stress-free environment. New Zealand tourism advertisements also targeted adventure and action in order to attract a specific subsection of the tourist market. 'Extreme' and 'exhilarating' activities promised the possibility of a new interaction with nature and intensive experiences in spectacular scenery. ${ }^{20}$ Even though such 'daring' activities take place in a safe and secure environment, they entail a colonial narrative that involves struggling against and, in the end, triumphing over nature using both sophisticated technology and physical skill.

New Zealand's anti-nuclear stance, which became world-famous when the Greenpeace ship Rainbow Warrior was attacked and sunk in Auckland's harbour, ${ }^{21}$ raised the country's profile in the $1980 \mathrm{~s}$. The Rainbow Warrior incident added to New Zealand's international reputation as 'green', 'clean', 'ecologically friendly' and 'politically correct', with staunch New Zealand individuals bravely standing up against the great powers. ${ }^{22}$ In New Zealand, visitors could supposedly put aside fears of environmental degradation and political disputes. They could even enjoy reminiscences of the noble (yet somehow civilised) savage, both welcoming and skilled in crafts.

In the late 1990s, New Zealand tourism promoters recognised the need for the creation of a stronger national profile in order to position the country more profitably in the increasingly competitive global tourist market. ${ }^{23}$ With the millennium celebrations approaching, New Zealand needed to be seen not just as beautiful, but also as distinct from both tourists' home countries and from other destinations. Sporting events such as the Rugby 
World Cup (1999) and the Americas Cup (2000) lent further encouragement to the importance of revising 'brand New Zealand'. Such occasions, along with political summits like the Asia-Pacific Economic Cooperation (APEC) meeting, hosted by New Zealand in 1999, provided opportunities to display the country to a global audience. ${ }^{24}$ The anticipated high media presence at these large events was an incentive to develop new marketing strategies and to find innovative responses to the globalised tourist industry's demands. Moreover, revised economic conditions and political constellations in several parts of Asia raised hopes of a new customer base: an affluent middle class, seeking leisure activities and consumption abroad, was emerging in the 'Asian market'.

In this context, the Tourism New Zealand Board decided to set up its first global campaign. It was designed by M\&C Saatchi and launched in 1999, thus facilitating efforts to attract tourists from the northern hemisphere for the new millennium. ${ }^{25}$ The revised national image needed to be in accord with the country's resources, meet consumer demands and be adaptable to target-specific segments of the diverse global tourist industry. ${ }^{26}$ The ' $100 \%$ Pure New Zealand' campaign satisfied all these requirements: it presented a powerful and distinct selling slogan and constituted an attractive generic brand which could be adapted for particular markets.

The notion of 'pure' is applicable to a wide range of things and is not restricted to the natural environment. Besides being used to conjure up images of undiluted, de-humanised and pristine nature, '100\% Pure' is also used to advertise local food and wine, designer accommodation, arts and crafts, Māori hospitality, adventurous outdoor activities ${ }^{27}$ and, more recently, exciting urban and sporting events in a country which is 'forever young. ${ }^{28}$ It is not just one image that is used to advertise New Zealand, as suggested elsewhere, ${ }^{29}$ because branding needs to be consistent, but does not necessarily require a single representation. The label ' $100 \%$ Pure' frames multiple facets and can easily be modified - ' $100 \%$ Pure Freedom', '100\% Pure Relaxation', '100\% Pure Bliss', '100\% Pure Adventure' - to meet specific marketing demands. It also allows for further adjustments to advertise distinct New Zealand activities or achievements, such as fashion shows featuring New Zealand designers with the slogan ' $100 \%$ Creativity'.

The ' $100 \%$ Pure' campaign aimed to reach an international audience through internet-based information and communication. Tourism New Zealand created a new website to provide detailed information for various constituencies, ranging from tourists to broadcasting professionals. ${ }^{31}$ Such web-focused strategies combined advertising, international media coverage, events and trade training to market New Zealand. They were in accord with Tourism New Zealand's goal of addressing 'the interactive and educated traveller' who is keen to explore. ${ }^{32}$ 
However, the ' $100 \%$ Pure New Zealand' slogan has spread far beyond the tourist market and is now attached to a large number of other products and ideas. The Green Party politicised the '100\% Pure' notion to oppose genetically engineered crops. ${ }^{33}$ Business people extended the motto when they created the ' $100 \%$ New Zealand - Keeping it Kiwi' campaign to promote New Zealand-owned and New Zealand-based companies as well as New Zealand products over foreign-owned businesses or imported goods. ${ }^{34}$ Thus, the notion of 'purity' has been applied to a variety of products, items, activities and ideologies, but it always implies something typical of New Zealand. Furthermore, 'purity' asserts authenticity and alludes to imitation and forgery elsewhere. It suggests that an audit has taken place and that New Zealand and its products have been measured, tested and finally certified as reliable and of the highest quality. ${ }^{35}$ It implies that test results are brilliant and that the country and its commodities are the best possible, ignoring the fact that 'pure' always signifies $100 \%$ - otherwise it is impure.

However successful Tourism New Zealand's advertising has been, it has been augmented by further representations of New Zealand made to a global audience. As another form of national branding, the film industry contributes considerably to the international commodification of New Zealand's scenic natural environment and fosters its entanglement in the global economy. The first film in The Lord of the Rings trilogy was released in December 2001, and the subsequent media publicity, which echoed earlier internationally successful movies such as The Piano (1993), was overwhelming. Thus, the creative industries' achievements add to a predominately positive international image of New Zealand, albeit by further mystifying the country. ${ }^{36}$

I now elucidate how ' $100 \%$ Pure New Zealand' is understood, translated and accommodated in the identity constructions of some Pākehā New Zealanders, and show how it is entangled with conceptions of the country and nationhood. I explore the ways in which meaning is attached to concepts of 'purity' with regard to New Zealand's self-image and the predominant themes of the country's repetitive representation, notably its evocative insularity and remoteness, its natural environment and its supposedly egalitarian social relationships. I argue that these perceptions are mirrored in dominant national discourses and reflect cultural hegemony.

\section{Pākehā identity and cultural hegemony}

People's relationship to the natural environment is central in New Zealand's processes of nation-building. 'Clearing the bush' and 'breaking in the land' were seen as key activities in the formation of the so-called 'national character'. ${ }^{37}$ In line with the myth of the pioneer, nature was conquered, simultaneously romanticised and portrayed either as majestic, sublime and overwhelmingly beautiful, or as mystical and dangerous. New Zealand's 
natural environment was also idealised in conjunction with the formation of an ideal society, ${ }^{38}$ and New Zealand's temperate climate was seen as conducive to 'racial improvement'. ${ }^{39}$ This settler mythology still resonates today, finding expression in New Zealand's male icons. It is particularly embodied and valorised in prominent national figures such as Sir Edmund Hillary, who climbed Mount Everest, or Barry Crump, a 'Kiwi bloke' who lived in the bush. ${ }^{40}$ These characters - associated with exploration, the outdoors and possession of, and power over, land - extend, impart and nationalise what was formerly the imaginary of the colonial adventurer. Thus, closeness to nature and a particular relationship with the natural environment and the outdoors are still perceived as important 'national features'. They are aligned with the frontier and colonial narratives, both of which remain integral parts of Pākehā's cultural heritage. This is reflected in the following accounts from Pākehā New Zealanders discussing 'New Zealandness' and their understanding of New Zealand's purity.

Helen traces her genealogy back to the nineteenth century, when her forefathers left Great Britain and migrated to New Zealand. The early decades of settling in a foreign country and building a new existence still play an important role in her family's oral history and are remembered with pride. While looking at photos and records documenting her family history, Helen points to the struggle with nature in the beginning of the colonisation process. She recalls stories of the hard life on her family's dairy farm and talks about rural hardship, exhausting activities like clearing trees and maintaining the house and shed.

Helen, who has never lived outside of Auckland and is proud of her urban lifestyle, naturalises New Zealand's identity and inscribes it in both its particular environment and early settlement history. She stresses the conquest of nature as crucial to the formation of the nation's distinctive qualities. She argues that New Zealanders went through a genetic selection process and only the fittest survived - implying that New Zealand's 'national' characteristics are shaped through interaction with the environment and intrinsically tied to the country's colonisation. This implicit claim of settlers' superiority alludes to a common rhetoric describing the first settlers as the 'best colonizing stock' - daring and fit enough to survive the hardship of the longest journey in the world ${ }^{41}$ - and as the cream of the British population'. ${ }^{42}$ When talking about national characteristics, uniqueness and the ' $100 \%$ Pure' advertisements, I asked Helen to give her ideas on the campaign. She affirmed New Zealand's representation as pure and referred to 'purity' in terms of the natural environment:

Yes, 1 think New Zealand is pure in so many ways. I just really care for our natural home. This New Zealand has got such a special and unique flora and fauna that is worth protecting and worth promoting over other 
species ... You can take that back a step and say it's like New Zealand has been isolated for 80 million years and that's why we evolved so differently [from the rest of the world] and only the best survived. And then if you got back to the original settlers they had faced horrendous icy voyages out here and only the strongest and fittest survived those to actually become the founders of New Zealand. So I think we have actually got a genetic capacity because of that. New Zealand has been through that selection process.

It is interesting to note that Helen parallels the selection of New Zealand's natural environment with the natural selection of the first settlers. In both cases, the best and the fittest survived, making the flora and fauna as well as the pioneers 'special' - that is, unique and superior. In addition, she ascribes divergent attributes to the natural environment and juxtaposes contrasting ways in which humans are supposed to interact with nature. While she perpetuates the colonial narrative and presents nature as hostile and challenging when talking about her family history and the settler context, she simultaneously conceives of New Zealand's nature as endangered, fragile and in need of human protection, care and management - in line with current discourses on ecological preservation and environmental awareness. These seemingly conflicting narratives express shifting perceptions of nature in accord with the respective historical or contemporary contexts. From a resource fit for exploitation and conquest, nature becomes an ecosystem in need of safeguarding and stewardship. ${ }^{43}$ In both cases, humans, especially settlers, are portrayed as masters of the environment, who seemingly either tame or administrate nature without harming it.

Helen relates the notion of purity to New Zealand's flora and fauna, and she tends to value native species over 'others' because of their uniqueness and quality, which she interprets as the result of New Zealand's isolation. The promotion of one species because it is native and 'pure', and the implicit classification of others as foreign and impure or polluting, suggests the existence of a naturally given ecological order, determining the belonging of particular species to a defined territory or eco-niche. ${ }^{44}$ 'Foreign' species are seen as 'less valuable' and 'less natural' because they do not 'belong' to a particular region but were imported by humans. In Helen's view, it has become humans' obligation to protect New Zealand's distinctive flora and fauna from eradication, something she understands in terms of ecological responsibility. While the 'native' is classified as 'pure', the 'alien' is conceived of as 'impure' or dangerous because it might threaten the native and, therefore, the 'legitimate' flora and fauna - and the most prominent national icons - of New Zealand. This perception resonates with an important strand in advertising New Zealand as shaped by isolation and producing, without human presence, 'fascinating native plants found nowhere else on earth but 
New Zealand'. ${ }^{45}$ Helen's understanding of 'New Zealandness' and 'purity' mirror this representation and both reflects and generates a particular national imaginary.

Isolation, distance and remoteness, which are recurrently evoked when New Zealand's endemic flora and fauna are advertised, have a particular relevance for Claire, a pensioner who has worked for many years for a transnational enterprise in Auckland. She still travels frequently and visits her daughter in London on a fairly regular basis. She perceives New Zealand as 'pure', 'green' and 'safe' because of its geographical location and recent colonisation. She gives particular emphasis to the insular nature of New Zealand, and is convinced that distance creates a sense of exclusive community, solidarity and collective identity. In her view, purity, insularity and identity are intertwined and mutually constitute each other. She believes that New Zealand's purity is preserved because of insularity, remoteness and the 'wildness of land', which she understands as a community-creating force that brings people together. In this vein, the global periphery, as opposed to 'the rest of the world', denotes safeness, unity and peace, which are at the heart of her sense of 'home':

It has always been a thrill to me when I have been overseas and I approach this huge green, green land, I just hope it will stay being green and being pure ... and also the fact we are two islands . . . and people who live in islands are particularly attached to their lands. It gathers people together because of the wildness of land. We are drawn together more. I feel like there is this closeness of people. We think about the rest of the world, we think, 'oh we are way down here, we are down under, we are not in all of that'. We feel like we are set apart ... Down here we are sort of safe together, because we are detached from the rest of the world.

This peaceful and harmonious perception of New Zealand is contradicted by a history of acute contestations over land and access to natural resources. The natural environment has not only been a source of solidarity, as expressed by Claire, but also of fierce debates about its potential profit, future development and utilisation. As in all settler societies, issues of land ownership and appropriation were crucial in the relationship between colonisers and indigenous peoples. Current competing interests fight over issues such as control, conservation, genetic engineering and organic farming. ${ }^{46}$ Nevertheless, Claire juxtaposes calm and serene New Zealand with unsettling and dangerous places in 'the rest of the world'. This harmonising view conceals conflicts, deprivation and change in New Zealand society, and reiterates the country's representation as a timeless, peaceful and static natural space that is not involved in or affected by disputes which belong to 'the rest of the world'. 
In this context, it is interesting to note that perceptions of New Zealand's geographical isolation have changed over time and acquired new meanings. While it was perceived as a hindrance to efforts to boost the tourist industry in the early stages of New Zealand's tourism development, the country's isolation has been turned into an attractive selling point in the light of globalisation and the quest for distinctiveness and difference. ${ }^{47}$ Today, the relatively long and expensive voyage adds to a sense of exclusivity at being able to get as far away as possible from everyday routines. New Zealand's image as static and unchanged because of its remoteness and insularity is used to suggest that visitors can indulge in the world the way it was before human interference changed its face forever. 'Untouched by the outside world', New Zealand's 'primal beauty' is preserved because of 'eighty million years of isolation in a time capsule' ${ }^{48}$ This beauty can be experienced in its original, timeless, 'pure' state by both the visitor and the local population. In this context, 'pure' means an environment devoid of human presence and activities, which are seen as potentially harmful to nature. The periphery - the 'edge of the world', which is protected by the sea - ensures security and distance from the overcrowded, urbanised and polluted centre. Such representations provide alternatives to notions of constantly shifting, hybrid and mixed formations, which constitute key identity markers in other parts of the world ${ }^{49}$ In times of terrorist attacks and contagious diseases like SARS, bird flu or HIV, New Zealand provides a safe, secure and politically stable destination..$^{50}$ In this regard, geographical distance, insularity and remoteness, combined with the South Pacific Islands' contrived appeal, have been turned into social capital and configured as integral parts of New Zealand's national profile.

In contrast to Claire and Helen, Andrew does not even mention the natural environment, remoteness or the endemic flora and fauna when discussing his ideas on New Zealand's representation as '100\% Pure'. In his view, New Zealand's purity refers to the colonial morality and political practice as expressed in the Treaty of Waitangi. Andrew, who is a student in his late twenties, proudly contrasts New Zealand's 'clean' colonialism with 'dirty' Australian practices. He explicitly refers to the Treaty of Waitangi as proof of distinctive, 'pure' historical and contemporary inter-ethnic relationships:

Australians miss out completely ... The Aboriginal was there first. I mean, at least the Pākehā in New Zealand say "the Māori guys were here first, but can we play too, can we share?" ... It [the land] was fortified and the guys were farming here and the Pākehā turn up and say "oh my god there is all this land, maybe we can talk about this" . . The first Australians did not negotiate with nomads and they haven't moved from that position in 300 years. That's where we have a plus though . . . I think that's part of being pure and clean, our relationships are based on 
some sort of respect that we find also in the Treaty of Waitangi which is always under discussion everywhere [laughs]. This might be related to being clean and having clean colonial relationship, I think so.

New Zealanders' idealised self-perception as anti-racist, liberal and egalitarian $^{51}$, as expressed by Andrew, is often present in popular discourses when the country is compared with Australia. This perception has several roots. It derives from divergent historical and contemporary policies regarding the indigenous populations in New Zealand and Australia, but also, as Chen suggests, from past shortcomings in New Zealand's scholarly representation of history. ${ }^{52} \mathrm{~A}$ further source of the idea that New Zealand is characterised by classlessness and equality is the popular, predominantly masculine, interaction pattern colloquially referred to as 'mateship'. This form of male camaraderie and symbolic bonding contributes to the disguise of social and economic hierarchies and unequal power relationships. ${ }^{53}$

In comparison with other indigenous peoples of the British Empire, the perception, evaluation and classification of Māori has often been favourable, reflecting nineteenth-century evolutionist ideas. Māori were considered more sophisticated or 'advanced' than indigenous groups like the aboriginal Australians. Appellations such as the 'Vikings of the Sunrise' alluded to Māori migration across the Pacific, which found appreciation in Western eyes and mirrored the settler experience. ${ }^{54}$ Although New Zealand colonisers were convinced that Māori would either assimilate and become Europeanised or die out, Māori were still involved in the nation-building process. Throughout much or all of the twentieth century, Māori possessed the right to vote, were acknowledged in the official census and participated in sport and war alongside Pākehā. ${ }^{55}$ However, this does not necessarily mean that Māori were included as equal partners in Pākehā perceptions of the nation. Rather, Pākehā colonists patronised and socially marginalised Māori. They ignored the Treaty of Waitangi or interpreted it to their advantage.

In Australia, no comparable document, treaty or policy existed, and to this day, indigenous groups in Australia are socially more disadvantaged and politically less empowered than Māori communities in New Zealand. This reality may well confirm Andrew's perception of New Zealand's relative purity, New Zealanders' 'respect' for indigenous peoples and their 'clean colonial relationship'. Nevertheless, it is important to note that while Australia is widely criticised for its 'White Australia' policy, New Zealand's political practice has been equally shaped by racist principles and policies, in particular with regard to so-called Asians. ${ }^{56}$ As in Australia, the need to 'guard the purity of race' was an important social and political issue in New Zealand in the late nineteenth and early twentieth centuries. ${ }^{57}$ The 'Yellow Peril' was perceived as a threat to the predominately white nation. ${ }^{58}$ Discrimination against 'Asians', in particular Chinese, was widespread and 
impacted on both the social climate and the cultural composition of the society. Prejudice found expression in a series of discriminatory laws from 1881 onwards and in the formation of 'The Anti-Chinese League' in 1895, later known as 'The Anti-Asiatic League'. Another example is the 'White New Zealand League', which also fought the perceived contamination of the nation. ${ }^{59}$ As a result of these exclusive policies, New Zealand was one of the most ethnically homogeneous settler societies up until the end of World War II. ${ }^{60}$ Discriminatory state legislation continued in the twentieth century when, in 1951, Chinese had to fulfil more criteria when applying for citizenship than applicants from other countries. ${ }^{61}$ In fact, New Zealand was the last settler country in the Pacific Rim to embrace non-discriminatory immigration laws in 1986-87.

These historical facts, along with ongoing violations of the Treaty of Waitangi, challenge the widespread perception of Pākehā New Zealanders as less racist than other colonisers. But they have long been neglected in historical writing on New Zealand. Chen critically states that racist policies are only briefly mentioned by New Zealand's earlier historians, whereas Australian scholars have sharply criticised such policies in their country's past. ${ }^{62}$ While she admits that anti-Chinese legislation is addressed in greater detail in more recent history books, she still concludes that disregard of racist policies and practices has resulted in an idealised, unrealistic selfimage, one in which claim is made to a non-racist 'national character', especially in contrast to the supposedly racist Australian one. Brooking and Rabel similarly argue that while this face of New Zealand history has been addressed in recent academic journals and monographs with small readerships, it is lacking in general and popular histories. ${ }^{63}$

New Zealand's representation as more tolerant and less racist than other nations is still present in public discourses. The Auckland City Settlement Strategy ${ }^{64}$ opens with a quote from prominent New Zealand historian Michael King, ${ }^{65}$ who optimistically posits that:

. . . most New Zealanders, whatever their cultural backgrounds, are goodhearted, practical, commonsensical and tolerant. Those qualities are part of the national cultural capital that has in the past saved the country from the worst excesses of chauvinism and racism seen in other parts of the world. They are as sound a basis as any for optimism about the country's future.

However, not only do historical records suggest caution with respect to King's conclusion, but so too do racist tendencies in New Zealand's contemporary society. Due to revised immigration laws in the 1980s, the country saw an unexpectedly high influx of 'Asian' ${ }^{\prime 6}$ migrants from the 1990 s onwards. Stereotypes and prejudice towards these new migrants has often been 
reinforced by media reporting, which has tended to focus on negative aspects of Asian immigration, such as rising property values, unconventional driving habits, pressure on the local infrastructure and tensions in schools created by the Asian migrants' presence. ${ }^{67}$ Anti-Asian sentiment was also used in political rhetoric during the 1996 election campaign. Indeed, there was a tendency to link Asian immigration and environmental issues. Conservative political forces argued that continuing 'Asian' migration to New Zealand constituted a 'pollution' threat to the country. ${ }^{68}$ In other images popularised by the media, Asians were seen as 'raping New Zealand's coastlines' through over-fishing, ${ }^{69}$ and they were said to come from dirty and overcrowded cities and to be unable to appreciate 'green and clean' New Zealand nature. ${ }^{70}$ More recently, Asian students have been described as 'by far the biggest litterers' in one newspaper." It is interesting to note that this perception of Asians is contradicted by studies investigating their reasons for migration. Many Asian migrants were actually attracted by New Zealand's representation as 'green and clean', as offering environmental advantages and a pleasant lifestyle and climate."

In the 2000s, the migration flow continues and the country's cultural composition is changing rapidly. In a relatively short period of time, Asian immigrants have overtaken Pacific peoples as the third largest demographic category within New Zealand after Māori and Pākehā New Zealanders. As the fastest growing 'ethnic group', in 2006 Asians represented $9 \%$ of the national population and are expected to comprise $15 \%$ by $2021 .^{73}$ While New Zealand's engagement with Asian popular culture and practices - through sports, arts, literature, cuisine, religions and festivals - is increasing ${ }^{74}$ and while New Zealand society is becoming more pluralistic and multicultural, this trend still causes ambivalent feelings in terms of national identity and self-perception amongst some New Zealanders. ${ }^{75}$ This is certainly the case with the Pākehā interviewees in this study. Claire expresses her feelings toward the changing face of Auckland:

I don't want to appear racist here, but I feel that Auckland is overrun with Asian students. It is appalling, all the filthy shops selling cheap Asian crap. I feel uncomfortable with all these new faces and I wonder what happened to Auckland, the city I loved so much? ... I do love Asian food, but I don't think that New Zealand should become an Asian country.

While discourses stigmatising Asian immigrants as 'polluting others' have emerged in other national contexts, ${ }^{76}$ they have a particular relevance in New Zealand, where the majestic landscape, its endemic flora and fauna and natural 'purity' are seen to contribute to the country's uniqueness. New Zealand's environment is not only a significant source of national pride and 
identity, ${ }^{77}$ but also of economic prosperity because of its commercial value for the tourist market and creative industries. Thus, perceptions of Asian migrants as threatening New Zealand's natural environment and 'purity' need to be understood in the context of the self-perceptions of New Zealanders and marketing slogans that draw on notions of a country that is 'clean', 'green' and 'environmentally friendly'. As these attributes are key markers in the internationally competitive tourist industry, they are significantly linked to the country's economy. In the views expressed by my interviewees, Asian New Zealanders have only just begun to be included in the country's representation and are not yet fully part of 'New Zealandness'.

\section{Conclusion}

New Zealand's predominately pictorial representation as a natural reserve - remote, static and 'pure', with empty landscapes and adventurous outdoor activities - and its depiction as a country of equal opportunities with an exotic but tolerant society are built on earlier representations which helped shape New Zealand's national and international reputation since its very first advertising campaigns. As with earlier brandings, New Zealand's most recent label ' $100 \%$ Pure' is not only associated with nature, but rather allows for endless imaginaries because of its vagueness and imprecision. It is meaningfully translated into identity formations as an idiosyncratic national feature, which distinguishes New Zealanders from 'others' who lack characteristics of 'purity'. Thus, branding images evolve beyond the tourist realm and reflect the conception of the society in which they are created and reproduced. They are intertwined with both local identity construction and foreign perceptions of place and nationhood.

The empirical findings of this study suggest that the Pākehā participants perceived their identity as a tentative national identity, one reinforced and legitimated by the ' $100 \%$ Pure New Zealand' global campaign. Indeed, the campaign provides a framework for hegemonic cultural forces as it conceals contestations over land, deprivation and racism. In many ways the campaign builds upon earlier ideas of colonial environmental relations. Non-Pākehā New Zealanders and international tourists may share notions of New Zealand's purity but translate these ideas in different ways, according to their cultural contexts. ${ }^{78}$ Designed as an economic project aimed at strengthening the country's position in the competitive tourist market by creating a unique and attractive profile, the ' $100 \%$ Pure' campaign, perhaps as an unintended consequence, reflects and naturalises local Pākehā understandings of 'New Zealandness' and national heritage. Branding and economic profiling for international markets are entangled with national identity and Pākehā identity. Together, these compose and reinforce each other, creating a sense of uniqueness and distinctiveness. Ateljevic and Doorne ${ }^{79}$ posit that national 
branding needs to be situated in the context of political processes and reaches far beyond economic interests. As an act of representation, marketing is always mediated through a set of cultural assumptions and reflects perceived social realities - in this case, those of the dominant cultural group.

New Zealand's national identity is constantly under debate. The country is becoming increasingly culturally diverse and its revised cultural composition requires the reformulation of identities and power balances. The controversy that recently emerged over the question of whether New Zealand is an 'Asian country' reflects the symbolic struggle over social and economic positioning and identity in a still Pākehā-dominated society. ldealised representations of New Zealand disguise racist tendencies and hinder a critical reflection on deprivation and discrimination. Instead, they reflect an image that favours dominant cultural groups by reinforcing their perspectives, while obscuring less comfortable social realities and competing cultural forces.

I 1. Ateljevic and S. Doorne, 'Representing New Zealand: Tourism lmagery and ldeology', Annals of Tourism Research, 29, 3 (2002), p.651.

2 Preliminary versions of this article were presented at the Stout Research Centre's 'Watching the Kiwis' seminar series, May 2007, and at the Council for the Humanities Congress, 'Transformations '07: Composing the Nation: Ideas, Peoples, Histories, Languages, Cultures, Economies', Victoria University of Wellington, August 2007.

3 In order to stress the Pākeha perspective applied in this article, I refer to 'New Zealand' instead of 'Aotearoa/New Zealand'. This is also in line with the majority of the advertising slogans of Tourism New Zealand (see Tourism New Zealand's websites, for example, http://www.tourismnewzealand.com).

4 I use the term 'Pākehā' for New Zealanders of European descent whose cultural heritage includes some reference to settlers. All participants in this research self-identified as Pàkehā and referred to the settler experience as an important strand in their family narratives and representations. The term Pākehā, as it is used in the wider society, is contested, and there is no agreed definition of its meaning (see for example J. Belich, Paradise Reforged: A History of New Zealanders from the 1880s to the Year 2000 . Auckland, 2001; P. Spoonley, Racism and Ethnicity. Critical lssues in New Zealand Society, Revised Edition, Auckland, 1993, p.57; A. Webster, Spiral of Values, Hawera, 2001; P. Spoonley, 'Becoming Pakeha: Majority Group Identity in a Globalizing World', in R. Patman and C. Rudd, eds, Sovereignty Under Siege? Globalisation and New Zealand, Aldershot, 2005, p.102).

5 I interviewed 19 participants, male and female, aged between 28 and 64 and living in Auckland. All are given pseudonyms. The interviews were conducted in 2006 and 2007.

6 M. Fairburn, The Ideal Society and Its Enemies. The Foundations of Modern New Zealand Society 1850-1900, Auckland, 1989, p.20; J.P. Taylor, Consuming Identity: Modernity and Tourism in New Zealand, Auckland, 1998, p.11.

7 B. Willmott, 'Introduction: Culture and National Identity'. in D. Novitz and B. Willmott, eds, Culture and Identity in New Zealand, Wellington, 1989, p.3.

8 Fairburn, pp.24-25, 42, 61.

9 B. Consedine, 'Inequality and the Egalitarian Myth', in D. Novitz and B. Willmott, eds, Culture and Identity in New Zealand, Wellington, 1989, p.174. 
10 K. Sinclair, A Destiny Apart: New Zealand's Search for National ldentity, Wellington, 1986, p.11; J. Phillips, A Man's Country? The Image of the Pakeha Male. A History, Auckland, 1987, p.26.

11 R. Steven. 'Land and White Settler Colonialism: The Case of Aotearoa', in D. Novitz and B. Willmott, eds, Culture and Identity in New Zealand, Wellington, 1989, p.32. It should be noted, however, as pointed out by Sinclair, that 245 women were running their own farms or sheep stations as early as 1874. Sinclair, p.215.

12 Consedine, p.174.

13 M. Ip, 'Maori-Chinese Encounters: Indigine-Immigrant Interaction in New Zealand', Asian Studies Review, 27, 2 (2003), p.233.

14 Sinclair, p.188.

15 Ateljevic and Doorne, p.654.

16 Ateljevic and Doorne, p.653.

17 By the late nineteenth century, the silver fern leaf was widely seen to represent New Zealand. By 1905, the kiwi (Apterygidae, one of New Zealand's flightless birds) had become the dominant national symbol. However, this and other symbols, such as sheep, kiwifruit or rugby, came to be more intertwined with popular culture than so-called high culture (Sinclair, pp.188, 190; A. Collier, Principles of Tourism: A New Zealand Perspective, Auckland, 2003, p.403; C. Bell, Inventing New Zealand: Everyday Myths of Pakeha Identity, Auckland, 1996, p.38; C. Bell and J. Lyall, The Accelerated Sublime: Landscape. Tourism, and Identity, Westport, 2002, p.15).

18 M. McClure, The Wonder Country: Making New Zealand Tourism, Auckland, 2004, p.217; C. McCarthy, Exhibiting Maori: A History of Colonial Cultures of Display, Oxford, 2007.

19 Although the tourism industry still mainly benefits Pākehā entrepreneurs, Māori owned enterprises play an increasing role in the tourist market. Most successful recent examples comprise eco-tourism activities like whale watching in Kaikoura or cultural shows, including the display of traditional village life in Rotorua, which focuses on the past rather than the present (McClure, p.276).

20 Bell and Lyall, p.270.

21 M. King, Death of the Rainbow Warrior, Auckland, 1986.

22 Bell, Inventing, p.51.

23 Collier, p.403.

24 McClure, p.282.

25 McClure, p.285.

26 Collier, p.405.

27 See the $100 \%$ Pure Television commercial at http://www.newzealand.com/travel/about -nz/features/features_home.cfm.

28 See the $100 \%$ Pure Television commercial at http://www.newzealand.com/travel/about -nz/features/super-tvc/super-tvc_home.cfm.

29 C. Bell, 'Branding New Zealand: The National Green Wash', British Review' of New Zealand Studies, 15 (2006), p.16.

30 Collier, pp.415-16; McClure, p. 286.

31 Collier, p.427.

32 See http://www.newzealand.com/travel/trade/about-us/tourism-new-zealands-role.cfm and http://www.cfperformance.com/shadozoom/portfolio/en/tourism-new-zealand.cfm

33 J. Fitzsimons, '100 Per Cent Pure or a Genetically Engineered New Zealand?', www .greens.org.nz/searchdocs/other6332.html, 2002.

34 New Zealand on the Web, 2001 ' $100 \%$ New Zealand - Keeping it Kiwi', http://100 .newzealand.co.nz/index.php. 
35 J. Bernanke, Paradise Misplaced: Tourism Imagery and Signs of Colonial Imposition, Wellington, 2001, p.10.

36 T. Jutel, 'Lord of the Rings: Landscape, Transformation, and the Geography of the Virtual', in C. Bell and S. Matthewman, eds, Cultural Studies in Aotearoa New Zealand: Identity, Space and Place, South Melbourne, Auckland, 2004.

37 Sinclair, p.8.

38 Fairburn, p.24.

39 J. Belich, 'Myth, Race, and Identity in New Zealand', New' Zealand Journal of History, 31, 1 (1997), p.13.

40 K. Pickles, 'Kiwi Icons and the Re-Settlement of New Zealand as Colonial Space', New Zealand Geographer, 58, 2 (2002), pp.9-10.

41 Sinclair, p.12.

42 Belich, 1997, p.13.

43 B.M. Newton, J.R. Fairweather and S.R. Swaffield, 'Public Perceptions of Natural Character in New Zealand: Wild Nature Versus Cultured Nature', New Zealand Geographer, 58, 2 (2002), p.27.

44 J. Olsen, Nature and Nationalism. Right-Wing Ecology and the Politics of Identity in Contemporary Germany, New York, 1999, p.6.

45 Tourism New Zealand, http://www.newzealand.com/travel/about-nz/nature/nature-home .cfm.

46 Bell, 'Branding', p.24.

47 Taylor, p.17.

48 See New Zealand Tourism Online, http://www.tourism.net.nz/new-zealand/about-new -zealand/nature.html.

49 See, for example, the Mexican/US border region or the Caribbean. A. Asgharzadeh et al., Diasporic Ruptures. Globality. Migrancy and Expressions of Identity, Rotterdam, 2007.

50 McClure, p.288.

51 Bell, Inventing. p.23.

52 M. Chen, 'Discrimination, Law, and Being a Chinese Immigrant Woman in New Zealand', Women's Studies Journal, 9, 2 (1993), p.15.

53 Phillips, p.30.

54 Sinclair, p.197.

55 Sinclair, p.204; Ip, p.233.

56 S. Brawley, "No "White Policy" in New Zealand', New Zealand Journal of History, 27, I (1993), pp.16-36.

57 See New Zealand Herald, 9 February 1906; see also the Weekly Graphic and New Zealand Mail, 12 August 1908, cited in Sinclair, pp.91-92.

58 T. Brooking and R. Rabel, 'Neither British nor Polynesian. A Brief History of New Zealand's other immigrants', in S.W. Greif. ed., Immigration and National Identity in New Zealand: One People, Two Peoples, Many Peoples? Palmerston North, 1995, p.24.

59 Sinclair, p.92; Ip, p.235.

60 Brooking and Rabel, p.36.

61 M. Ip and D. Pang, 'New Zealand Chinese Identity: Sojourners, Model Minority and Multiple Identities', in H. J. Liu, T. McCreanor, T. McIntosh and T. Teaiwa, eds, New Zealand ldentities: Departures and Destinations, Wellington, 2005, p.179.

62 Chen, p.15. Chen's observation is based on O'Connor's critique of New Zealand's history books. See P.S. O'Connor, 'Keeping New Zealand White 1908-1920', in New Zealand Journal of History, 2 (1968), p.41.

63 Brooking and Rabel, p.23. 


\section{Journal of New Zealand Studies}

64 Auckland City Council, Settlement Strategy. A bridge to our new people, Auckland, 2005.

65 M. King, The Penguin History of New Zealand, Auckland, 2003, p.520.

66 The diversity of the new Asian immigrant groups is homogenised in dominant public discourse, which classifies them simply as 'Asians'. This label refers usually to EastAsian migrants.

67 J. Lidgard, East Asian Migration to Aotearoa/New Zealand: Perspectives of Some New Arrivals, Hamilton, 1996, pp.3. 44; R. Vasil and H.K. Yoon, New Zealanders of Asian Origin, Wellington, 1996, p.24.

68 M. Ip and N. Murphy, Aliens at my table: Asians as New Zealanders see them in Auckland, N.Z., Auckland, 2005, p.154.

69 Ip, p.246.

70 Ip, p.246; Chen, p.6.

71 The New Zealand Herald, 24 December 2003, 26 December 2003 and 16 June 2004. See also E. Dürr. 'Tidy Kiwis, Dirty Asians: Cultural Pollution and Migration in Auckland, New Zealand', in E. Dürr and R. Jaffe, eds, Urban Pollution: Cultural Meanings, Social Practices, forthcoming.

72 W. Friesen and M. Ip, New Chinese New Zealanders: Profile of a Transnational Community in Auckland', in W. Friesen, M. Ip, E. Ho, R. Bedford and J. Goodwin, eds, East Asian New Zealanders: Research on New Migrants, Albany, N.Z, 1997, pp.6. See also R. Chui, 'Auckland's 'Economic Immigrants' from Asia', in I. Cater, D. Craig and S. Matthewman, eds, Almighty Auckland?, Palmerston North, 2004, pp.111-34.

73 Statistics New Zealand, http: //www.stats.govt.nz/analytical-reports/dem-trends-05/default .htm, and http://www.stats.govt.nz/census/2006-census-data/quickstats-about-culture -identity/quickstats-about-culture-and-identity.htm?page=para015Master.

74 H. M. Johnson and B. Moloughney, eds, Asia in the Making of New Zealand, Auckland, 2006.

75 See the survey by P. Gendall, P. Spoonley and A. Trlin, 'The Attitudes of New Zealanders to Immigrants and Immigration: 2003 and 2006 Compared', Occasional Publication No. 17, New Settlers Programme, Palmerston North, 2007, p.10.

76 K. Mitchell, Crossing the Neoliberal Line: Pacific Rim Migration and the Metropolis, Philadelphia, 2004, p.182.

77 Bell, Inventing, pp.46-47.

78 Dürr, forthcoming; E. Dürr, 'Arcadia in the Antipodes: Tourists' Reflections on New Zealand as Nature Experience', SITES. A Journal of Social Anthropology and Cultural Studies. Special lssue: Mobility, Migration and Multi-culturalism in New Zealand, 4, 2 (2007), p.57-82.

79 Ateljevic and Doorne, p.649. 